\title{
Beneficial effects of public sector performance measurement
}

UDK: $35.077: 658.652$

\author{
Neda Vitezić \\ University of Rijeka Faculty of Economics \\ nevit@efri.hr
}

\begin{abstract}
Recently, major attention has been devoted to performance measurement in public sector, especially from the aspects of qualitative assessment. For that reason the financial performance measures are limited in overall assessment of an organisation performance. There are also difficulties in quality measurement because of a variety of different services and their intertwinement. New tools, such as balanced system of indicators, customer relation management, benchmarking etc. are subjects of research and implementation. Transition countries follow the trends in developed countries; thus, the obligation to monitor and provide information on public sector performance becomes a part of their legislature. This primarily refers to spending of public revenues, i.e. rationality of performance, while the qualitative aspect or effectiveness is still not measured. The problem lies in the need for a clear vision definition and in goal setting. Realisation of goals and their measurement is related to a well-set strategy and reasonable planning, as well as the selection of adequate indicators. However, the fact remains that setting of measurable goals prompts responsibility of executive power and individuals, as well as transparency in reporting. The benefits of performance measurement become evident also in the practice of emerging countries, and they are related to behaviour changing, transparency, accountability, organisation and leadership improvements, and willingness to learn and to innovate processes.
\end{abstract}

Key words: public sector, performance measurement, effectiveness, emerging country

\section{Introduction}

More than ten years ago, researchers and practitioners started to appoint performance measurement systems which should be "relevant, integrated, balanced, strategic and improvement-oriented" (Umit S. Bititci et al, 2005, p.335). Also, there is growing awareness that financial measures are not sufficient for planning and controlling purposes in both private and public sector. However, although the criticised financial indicators are still widely used in 


\section{Neda Vitezić \\ Beneficial effects of public sector \\ performance measurement}

many aspects of performance measurement, especially for analysing the short-term performance, the implementation of a more broadly based set of performance measures is more useful for analysing the achievements of longterm strategies. For efficiency purposes, managers consider financial indicators to be useful, but for assessment of the effectiveness of individual tasks and of long-term goals, other quantitative and qualitative non-financial indicators are more useful. (Vitezić and Knez-Riedl, 2005, p.248)

Today, the environment is very complex, and globalisation implies that new visions, strategies and objectives should be measured in a different way. In such competitive environment, there is a need for a new measurement system which would be adjusted to the purposes of sustainable development of firms. Public sector could not escape these general trends, and its comprehensive performance measurement system is more evident in comparison with other sectors. Democratic growth which strengthens the level of public participation in decision-making becomes more and more obvious. Also, the behaviour of people and their attitude towards public services are changing. They not only want to be informed, but also to be involved in the decisionmaking process. While democratic participation grows, there is increasing pressure of citizens and legislation that demand more responsibility in spending of public revenues and transparency in reporting on the achieved results. This reflects on the local government, which becomes more responsible in money expenditure and more effective in its actions. As Bill Hansell (2002, p.36.) said, "managers must be champions of economy, efficiency, effectiveness, equity and ethics in the long term interest of the entire community". Effectiveness and efficiency are emphasised as well as economy and they are very important for public sector performance. Outcomes replace outputs, and for measuring outcome, there is a need for qualitative assessment. This is not easy in public sector because of many practical difficulties in measuring of intangible elements.

Performance measurement is a very useful tool in the improvement of public services. Lately, there has been a lot of discussion about the New Public Management (NPM) concept, with no universally accepted definition (Adcroft and Willis, 2005, p.387). NPM could be defined as a management culture that emphasises the centrality of the citizen or customer, as well as accountability for results. (Pidd, 2005, p. 484.). Some researchers like Hood (1991, p.4-5) suggest that NPM consists of different doctrines, including more emphasis on "professional" management, introduction of explicit measures of performance, focus on outputs and results and greater role played by "private sector style" of management. 


\section{Some limitations in performance measuring in the case of Croatian local government}

"Performance" is a complex word implying action, dynamics, and effort for improvement, and from the point of view of the local government or service, it is also multi-dimensional. Public services today are more and more oriented on profit and performance measures fall within the end results expressed through competitiveness and financial gain. Some authors (Ghobadian and Ashworth, 1994) identified several main types of services: professional shops, service shops and mass services, and for all of them, quality, flexibility, resources utilisation and innovation are important. Measures which did not differ within the framework of previously mentioned three types of services are: competitiveness, liquidity, capital structure and market ratios.

While they attempt to increase the quality of service performance, one of the main objectives of the heads of local governments is improvement of operational efficiency and effectiveness, as well as efficiency of programme implementation.

The research is based on an interview with internal auditors in three local governments (County of Primorje-Gorski kotar, Town of Rijeka and Town of Crikvenica). The questions referred to organisation of work, technical and technological equipment, competence of human resources and management. The following limitations have been identified based on the obtained answers:

Table 1: Key Limitations

\begin{tabular}{|c|c|c|}
\hline Internal process & Technology & $\begin{array}{l}\text { Management \& } \\
\text { Leadership }\end{array}$ \\
\hline $\begin{array}{l}\text { - Week internal control } \\
\text { system }\end{array}$ & $\begin{array}{l}\text { - Lack of developed } \\
\text { information and } \\
\text { communication } \\
\text { system }\end{array}$ & $\begin{array}{l}\text { Unclear definition of } \\
\text { vision and strategy }\end{array}$ \\
\hline $\begin{array}{l}\text { - Lack of employees' } \\
\text { skills }\end{array}$ & $\begin{array}{l}\text { - Lack of adequate } \\
\text { equipment }\end{array}$ & $\begin{array}{l}\text { Week performance } \\
\text { measurement system }\end{array}$ \\
\hline - Resistance to change & - Lack of knowledge & - Interference of politics \\
\hline
\end{tabular}

Source: Survey Results 


\section{Neda Vitezić \\ Beneficial effects of public sector \\ performance measurement}

Certain actions are being undertaken in order to reduce these limitations. They primarily relate to:

- Introduction of internal financial control

- Introduction of programme-planning

- Education of internal auditors

- Modernisation of the information system

- Depoliticisation.

In Croatia as a transition country, the process of public administration reform is underway with the purpose of increasing its efficiency, fiscal disburdening, increasing competence and impartiality of public administration employees. Among the series of measures, transparency in reporting on public finance in accordance with the methodology of International Monetary Fund (GFS 2001), methodology of the EU (ESA 95) should be emphasised for the purpose of comparison of fiscal data with those of other countries. Croatian public administration is still in the process of drafting the methodology for the statistics of public finance, especially statistical indicators and establishment of the efficient and sustainable statistical system. In relation to performance measurement by means of legislation (Finance Act), local authorities are obligated to involve the following elements in the budget:

- Basic economic sources for the draft proposal of the budget,

- Description of the planned policies,

- Assessment of revenues and expenditure and financing for the period of three years,

- Framework proposal of the financial plan,

- Procedure and work schedule for drafting of the budget and financial plans of budget beneficiaries.

Financial aspect of the business process continues to be the most important segment of public administration management, so the financial aspects of measurement are still the only indicators of success. The emphasis is on realisation of the plan, setting of short-term goals and measures. Because of the lack of vision and strategy, the efficiency of long-term programmes and realisation of goals have not been monitored yet. Although the Act has foreseen programme planning and reporting on the achieved goals, it has still not been performed in practice. Shortcomings are still present, although the Act regulates that every programme must be based on:

- Legal and other regulations, 
- Assessment of the required resources along with argumented indicators,

- Reporting on the achieved goals and results of the programme with argumentation of the most significant activities,

there is still lack of information on lost effects in case of non-realisation of programmes. Also, responsibility for oversights is frequently avoided.

However, the greatest problem lies in determining and systematisation of adequate measures and insurance of the information system. Efficiency and effectiveness are the key principles in public administration performance, but their measurement standards have been negligibly developed, and only in service-oriented departments. The fact is that the measurement process is easier when it comes to delivery of services; however, it is basically reduced to the effects expressed numerically in relation to the plan. The qualitative aspect of measurement, i.e. effectiveness, has been underestimated, although it is the most important measure of public administration performance.

\section{Problem area of qualitative performance measurement}

Public sector performance does not significantly differ in individual countries, but various degrees of democratisation, as well as decentralisation of resources can have an influence on the level of organisation and on public administration management. The mission of the public sector is basically the same everywhere, and it is determined by the size and level of development of the society, but also by management abilities of the elected officials and performers. However, political influence is also possible, especially in the multiparty system which is to a great extent present in Croatia, as well as in other transition countries. Lack of demarcation between political and non-political decisions can jeopardise efficiency and effectiveness of the provided services. In most cases in public sector, the competitiveness concept is non-existent, except when it comes to provision of individual services.

The key success factor in the public sector is achievement of a satisfactory level of the mission or purpose. However, this depends on the series of factors related to the efficiency of the internal organisation, as well as output and outcome to external users. The goal is not to achieve the greatest profit or return possible, but the highest level of customer satisfaction. In some cases, it is possible that the demands and goals of customers are unclear, so searching for effective and efficient metrics might sometimes be very difficult. 


\section{Neda Vitezić \\ Beneficial effects of public sector \\ performance measurement}

Characteristics of public sector performance measurement are the following:

- Liabilities, i.e. expenses are measured often, and results rarely,

- Qualitative aspect of services i.e. the outcome, is not measured,

- Utility services are measured more often then other types of business activities,

- Measurements are not thorough and continuous,

- Measurement does not reflect target value,

- The plan is not connected with the goal and strategy.

Multidimensionality in public sector performance forces organisations to be bound to the desired outcomes. Thus, the key measures of performance are productivity, efficiency, effectiveness and quality. Audit Commission (1986) emphasised two key elements: efficiency and effectiveness. Service efficiency was defined as the "provision of specified volume and quality of service with the lowest level of resources capable of meeting that specification" and effectiveness as "providing the right services to enable the local authority to implement its policies and objectives." There is also a third element - economy, although included in efficiency, but specifically emphasised in the context of purchases from outside, defined as "the lowest possible cost consistent with the specified quality and quantity."

The concept of "economy", "efficiency" and "effectiveness" has been well known in the public sector for more than ten years. However, it is interesting that this concept is still not acceptable in practice to its full extent. Especially, there are still difficulties in effectiveness measurement, which requires more qualitative data. Regardless of difficulties in quantification of inputs/ impacts, they have to be considered. There are still difficulties in effectiveness measurement which require more qualitative data. Because of the complexity of public measurement system, which consists of various factors, there is a problem of data collection and interpretation. Moreover, there is no unique or standard measurement system for performance assessment.

Characteristics of public sector performance have determined the measurement system which is oriented to efficiency and effectiveness principles. Managing process is oriented to efficiency indicators, i.e. assessment of how much of the "service" was generated, and the governing process is oriented to outcome indicators in order to assess the effects of different policies in meeting all of the stakeholders' needs, especially those of customers. 


\section{Figure 1: Performance measurement process}

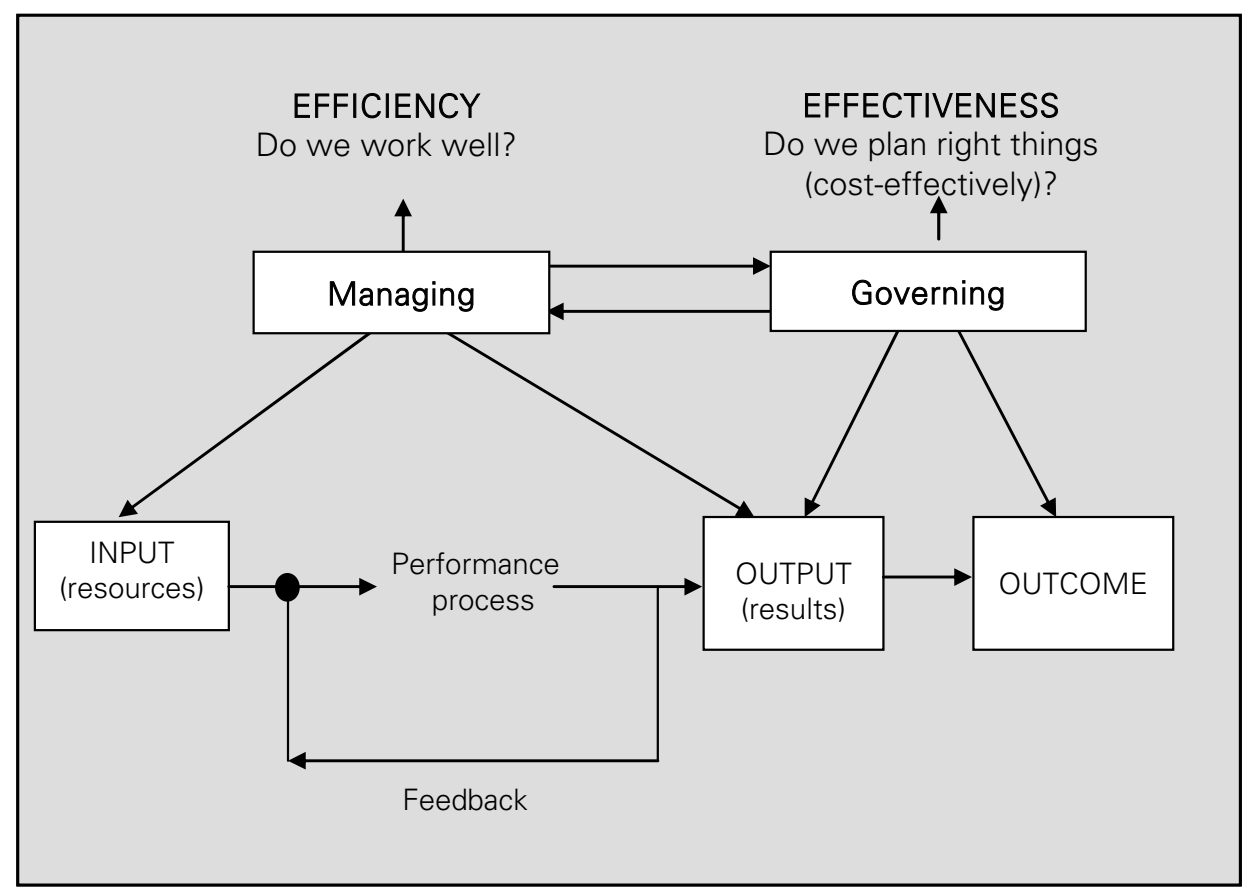

Source: Author's Research

Qualitative assessments and measures of effectiveness are usually addressed to the services because their productivity and efficiency can be examined easier. The key issues in the process of performing services are mostly related to the efficiency of the service, especially from the point of delivery. Measuring costs and quantities with no regard for quality is not a satisfactory basis for performance review. Thus, quality of service and effectiveness in meeting needs are the goals of performance measurement.

For example, public transport is usually measured by efficiency and economy indicators - mostly outputs - as in how many new buses there are, the number of buses per lines, how many passenger miles, how much cost per citizen will be paid by authorities etc. Effectiveness outcomes which should be measured provide answers to questions: did we make waiting time on bus stations shorter, did we improve the quality of the mobility of citizens and ensure their faster arrival to work, without taking their own cars etc. Of course, the goal should be reducing the number of cars, which park in the town centre. Although quality assessment is more complex, it could be measured if the goal is properly placed. 
Neda Vitezić

Beneficial effects of public sector

performance measurement

Table 2: Examples of inputs, outputs and outcomes

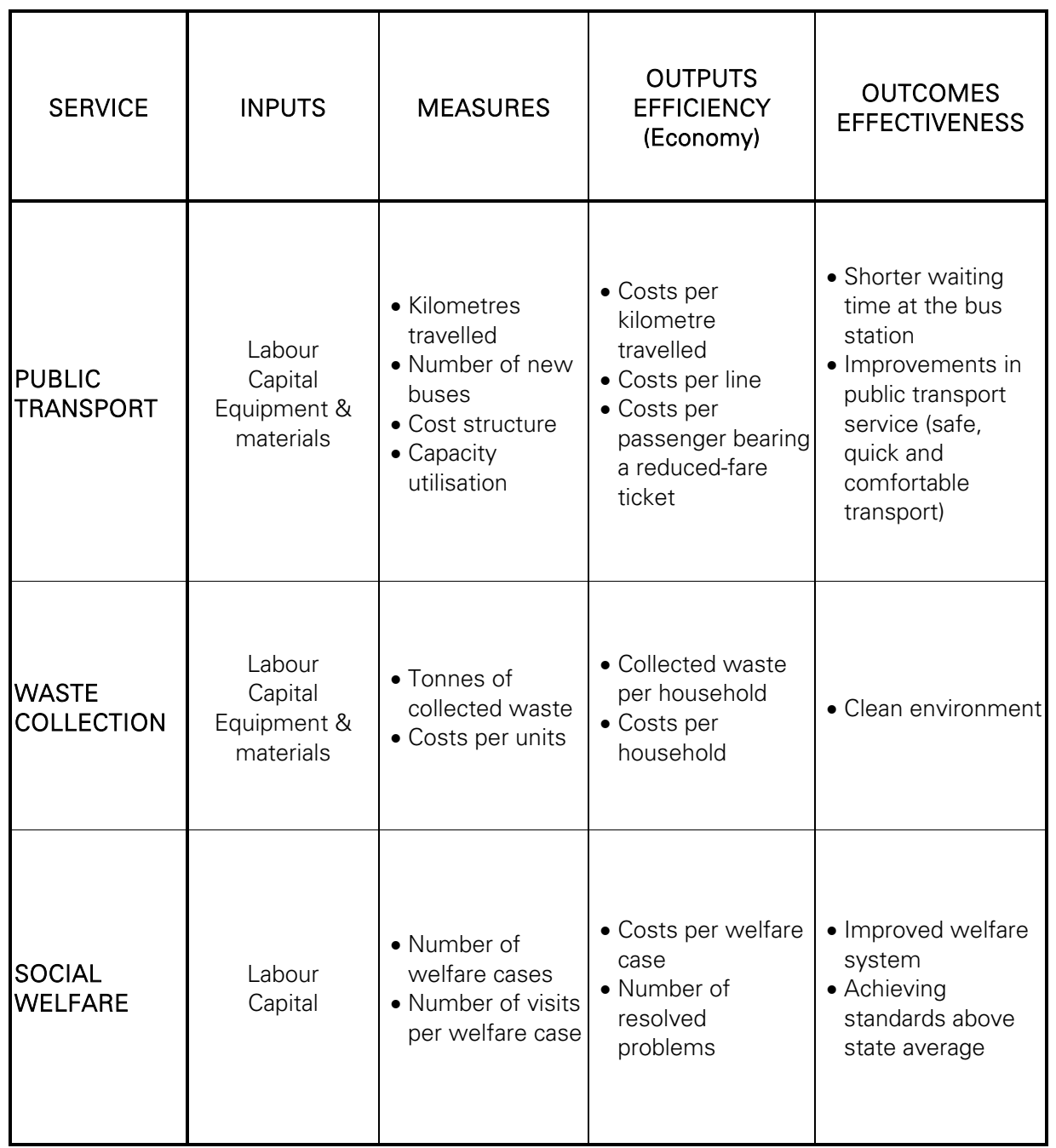

Source: Author's Research

Depending on authorities in emerging countries, the definition of the "3E" concept is still unclear and interpreted in different ways. The reasons for this are attitudes and organisational arrangement, diversity of tasks, technical difficulties, level of knowledge and skills. The focus of measurement has so far been internal and primarily concerned with efficiency, particularly economy. This is easier because of the output tangibility, which is mostly expressed in money value. Performance is measured through relationship between economic inputs and outputs. Measures are mostly related to labour and capital productivity, return on investment, customer satisfaction, service quality and 
other with the same end, and they answer to the same question: "How much will the organization get out from the investment that is put in?" This simple notion is relatively easy to measure, but the problem could emerge in cases when the subject of measuring is the process through which the assessment has been made. Complexity is affected by market conditions, industry structure, social benefits, law requirements, knowledge etc. Thus, a greater problem could emerge in measuring of outputs. The selection of procedures and ultimate outcome measure depend on the reason for introducing performance review and measure system. Normally, measures have to be related with the set goal and mission.

\section{Usefulness of the balanced scorecard approach}

Fifteen years ago, Kaplan and Norton (1992) established a new model of performance measurement and management. This model has been operative to this day, especially in private sector, but in the past few years, it became a subject of research in public sector as well. Balanced scorecard could be seen as a useful model to local authorities and others in public sector for measuring their performance improvement. Kaplan (2001) also points out that the scorecard offers a variety of benefits to public sector, like closing the gap between vague mission and strategic goal statements and operational activities and measures. Moreover, the scorecard helps to shift the focus away from individual initiatives and programmes to the outcomes that such initiatives might achieve. Scorecard is also useful for external performance reporting and as a measure of local authority and government accountability.

In Croatia, balanced scorecard has had greater appeal to the private sector, but in the public sector there is still a lack of knowledge of its usefulness. As emerging country, Croatia accepted all the rules and laws in accordance with EU requirements or general principles. From the aspect of public sector management, there have been some changes in the revenue structure, its distribution (greater decentralisation), accounting records, financial reporting and auditing.

In literature, there are many modifications of the BSC in private or public sector. However, Figure 2 shows a modification of the balanced scorecard approach from the point of the situation in the public sector of a transitional country. 
Neda Vitezić

Beneficial effects of public sector

performance measurement

Figure 2: Balanced scorecard approach

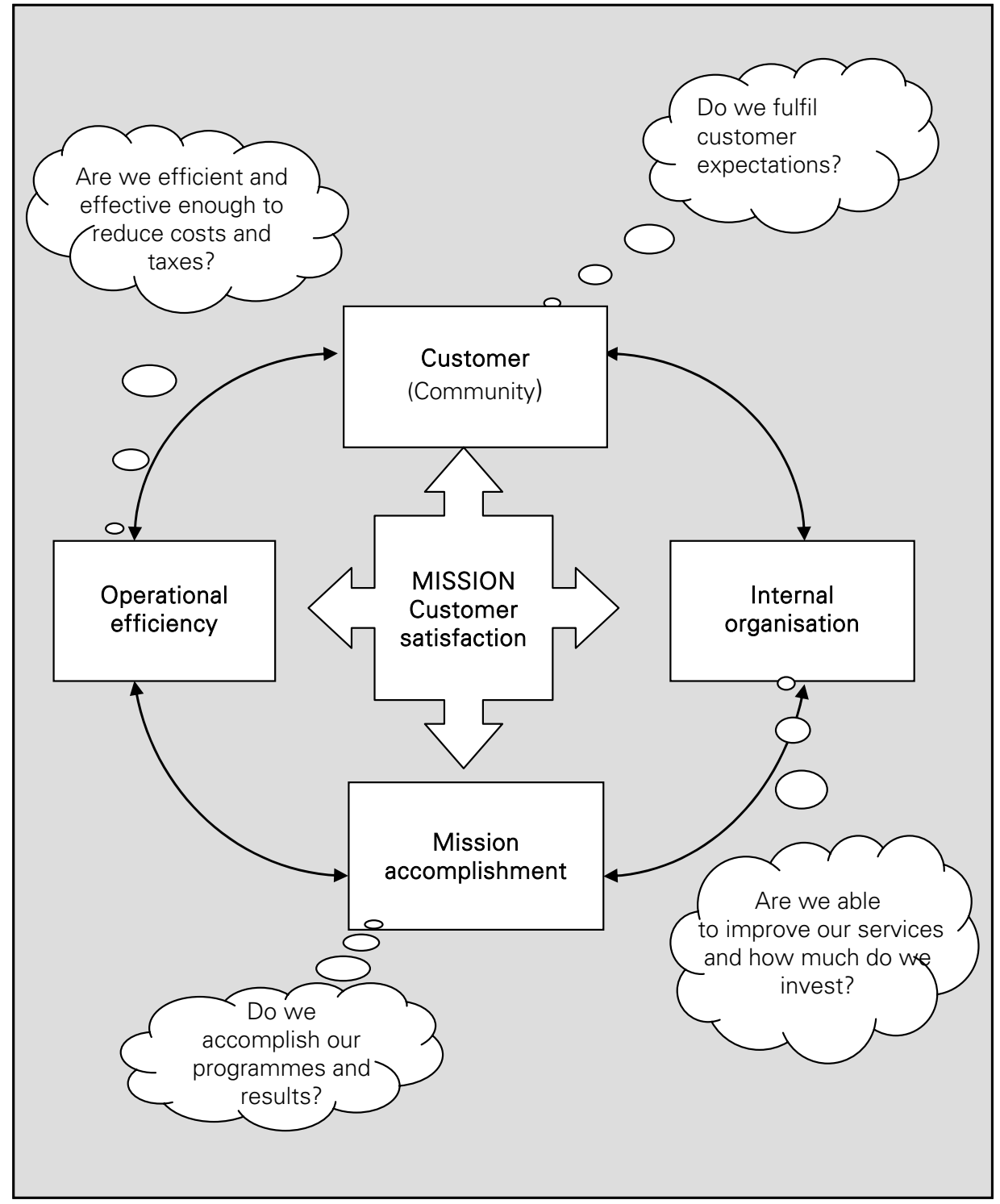

Source: Modified BSC based on Kaplan and Norton Matrix

There are over 130 books, articles and cases on the balanced scorecard, and the Harvard Business Review has called the balanced scorecard one of the most important management ideas in the last seventy-five years (Myer, 2002, p.2). The model is still subject matter of much research and it is performed in both private and public sector. However, the sectors differ, and the 
"four main perspectives" are changed from the point of view of public mission and performance. Orientation to quality measures and effectiveness in public sector performing sustains applicability of the BSC. Finding proper measures and balancing them among the main perspectives is currently most important. Still, there remains a problem of the usefulness of financial indicators, which has in the last decade also been criticised as maladjusted in terms of measures for the so-called "new environment". In the public sector, financial measures such as profitability or liquidity are not important for several reasons. First, the goal is not to make profit, but rather to make the life of citizens as comfortable as possible, and secondly, resources are limited and depend on taxpayers' payments. Liquidity is a problem in most Croatian private firms, but in public sector it is not, because in public sector the planning system is in accordance with disposable resources. Thus, the modified balanced scorecard remains a very useful tool because it prompts to reconsideration of the achieved goals in accordance with the set mission. However, the mission is realised if the strategy has been set and if the adequate plans have been set. This is often not the case in the Croatian public sector, that is why the model has not been implemented. There is also a problem of selection of adequate measures which have to be related and synchronised in order to provide answers to questions asked in the framework of each perspective. This is another problem, because it depends on the set goal, as well as professional skills and knowledge of management and employees, as well as informationcommunication connections and available technology.

\section{Implementation and realisation of an infrastructural community programme of public area maintenance (hypothetical example)}

In order to implement performance measurement systems and BSC as a tool, first and foremost, there is a need to define vision, mission and goals.

Mission: Local government of the City of Rijeka shall ensure all its citizens and visitors life and stay in a regulated and healthy city.

The mission should be adopted after discussion on the level of local authorities and it should include citizen participation. Citizens should become involved in the process of carrying out and adopting the programmes, and they should take part in goal-defining as well. 


\section{Neda Vitezić \\ Beneficial effects of public sector \\ performance measurement}

Goals:

- to increase cleanness of city streets and public areas

- to arrange green areas and lines of trees

- to decrease the number of unauthorised landfills

- to decrease sea and air pollution

Objectives:

- to increase the frequency of waste collection for $30 \%$ in year 2007

- to increase cleanness of streets and squares in Zone I for $50 \%$ in 2007

- to increase the arrangement of green areas for $20 \%$

Action Plan:

- to increase the number of locations on which waste is collected for $10 \%$

- to increase the frequency of sweeping in Zone I and to widen the cleaning area

- to increase the number of mowing actions; the suggested mowing height is $10 \mathrm{~cm}$

Realisation of the mentioned objectives and plans generates a certain amount of costs which should be predicted in financial plans. Although total costs could increase, direct and indirect beneficial effects should be significant. For example, greater satisfaction of citizens and tourists could have an influence on higher sales, as well as decrease of diseases caused by uncleanliness. Performance measures should be determined for each objective.

For example, collection of selected waste (batteries, medical and chemical items, glass, various kinds of plastic) requires a greater number of containers, and the citizens should be educated on advantages of this kind of collection. At the same time, the quantity of disposed domestic waste decreases and cleanness increases. This should have an influence on different calculation system of utility rates, because selected waste could be sold as secondary raw material. Citizens benefit from lower utility rates and get to live their life in a cleaner city. The result (output) of selective waste collection could be measured through comparison between the quantity of waste, transportation costs and disposal of domestic waste, and the comparison of the costs of selected waste with sales revenues from utility charges and sales of the collected waste. The outcome is a cleaner city, and the level of cleanness could be measured in different ways: by examination of cleanness, defining 
the standards of cleanness, monitoring the number of unauthorised landfills, designing a questionnaire for the citizens etc.

\section{Figure 3: BSC for Community Service}

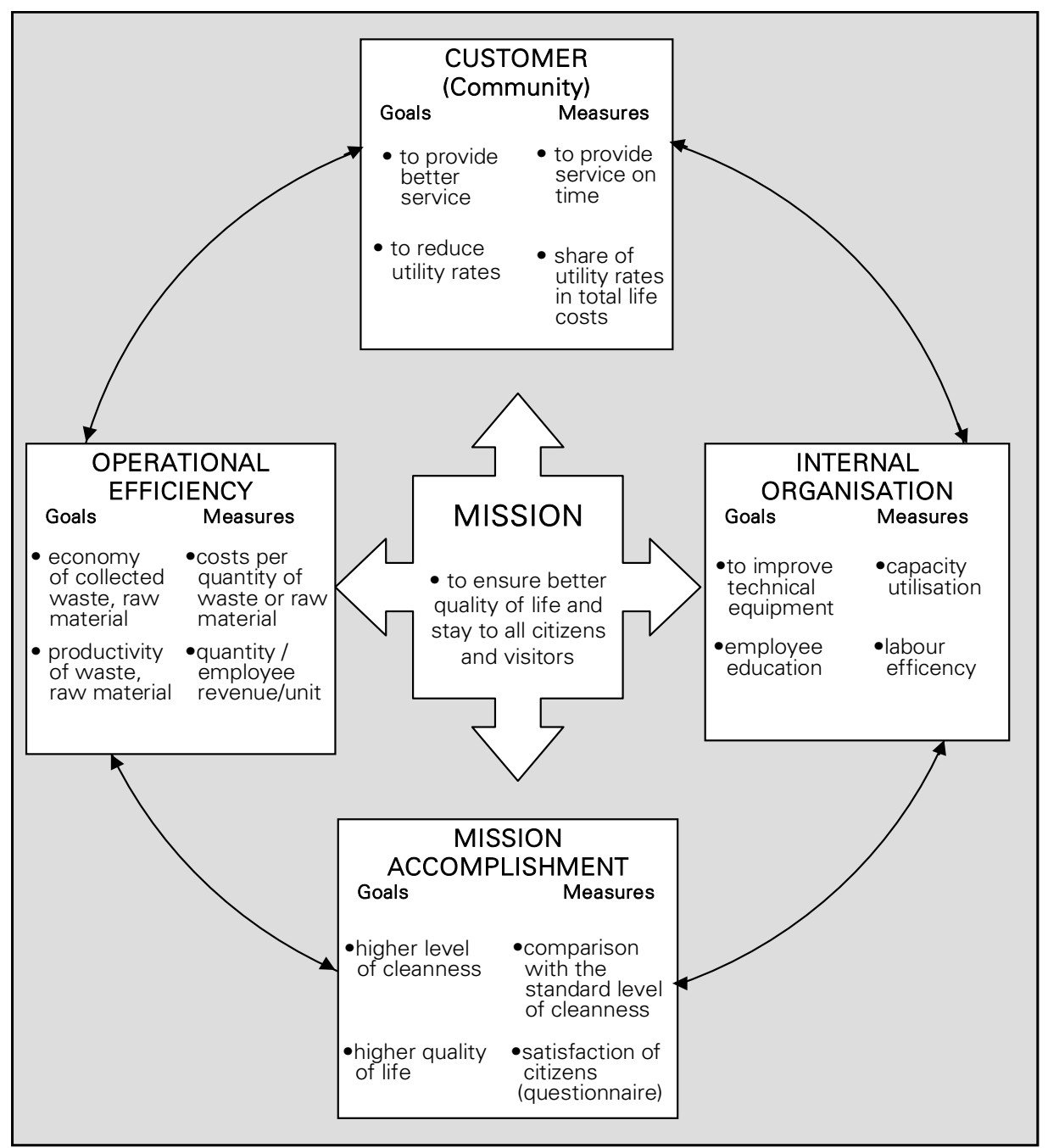

Source: Author's Research (Hypothetical Example)

Determined goals and measures are in balance according to perspectives. Operational efficiency and internal organization will lead to citizen (customer) satisfaction and mission accomplishment. 
Neda Vitezić

Beneficial effects of public sector

performance measurement

\section{Beneficial effects of performance measurement}

To answer the question which are the beneficial effects of performance measurement, it is necessary to explain why it is necessary to measure performance in public sector. Obviously, to get an insight in what we do and how much we have done. Moreover, to see how well we do a certain job and satisfy expectations of citizens. It is also a confirmation of justifiability of our workplace, as well as an accountability measure for the performed job. A prerequisite for setting demands for performance measurement primarily has to be clearly expressed through awareness and willingness of the management structures to show the results of their work and justify the confidence of citizens who elected them. Also, there is a necessity to determine the need for measurement through the establishment of legislative regulations. Ultimately, a prerequisite is also development of a high level of democratisation, which enables the customers to be included in the decision-making process.

According to Meyer (1994, p.101), performance measurement is useful in so far as it can "tell an organisation where it stands in its effort to achieve goals". Drucker (1995, p.23) discusses the benefits in terms of generating new and additional resources, clearer understanding of economic chains and wealth creation. In their discussion of the balanced scorecard, Kaplan and Norton $(1992$, p.124) suggest that the benefits are in the translation of the "company's strategy and mission statement into specific goals and measures" which allow for "products to market sooner and innovative products tailored to customer's needs". It is evident that setting objectives and goals in accordance with strategy, and choosing proper performance measures systems provide the rationale for management action. Moreover, performance measurement systems stimulate management to act responsibly because of transparency in reporting.

From the view of the public sector performance in an emerging country, the positive side of performance measurement system could be abridged in the following statements:

The first benefit is related to changing in behaviour of authorities and understanding the need for setting of measurable goals. Qualitative side of measuring is particularly important, as well as setting up the indicators of effectiveness. Taking into consideration all difficulties in terms of quality, performance assessment is very important in public sector. It is important that the thinking patterns have changed and that people started looking for solutions to the question how to satisfy wide range of interests in the society. Interests of 


\section{Neda Vitezić \\ Beneficial effects of public sector performance measurement}

citizens - customers of public services come first, but also the interests of taxation and other government institutions, as well as all others that are directly or indirectly connected to providing public sector services.

The second benefit is transparency and accountability. These two issues are principles in accordance with the governing process. OECD principles (2004) are applicable to public sector, although they are primarily focused on private management. Performance measurement system forces local authorities to set strategy and goals, changes thinking patterns on mission and vision. At the same time, this means that it imposes transparency in reporting, not only of certain institutions and bodies, but also of informing the citizens of the expenditures and the achieved results for the well-being and social benefits of all beneficiaries. This induces moral accountability of the officials towards their constituents and the society as a whole in order to make the right decisions and to implement them efficaciously. Also, it enhances accountability of all the employees in public administration for regularity and consistency of their performance. Measuring and transparency of performance contribute to efficiency of the employees because they are familiar with the purpose and aim of their work. In many organisations, it is unclear what the employees contribute to the process and to goals of the organisation. Transparency helps them to realise their role and to benefit in achieving strategy and their objectives.

The third benefit of local and state officials and managers is leadership, which is much better when there is a measurement system for execution of tasks and work results, especially of the set goals. Performance measurement improves policy and the decision-making process, because everything is visible. Moreover, it is a confirmation of a policy and decisions which are carried out properly, as well as an incentive for external accountability.

The fourth advantage of performance benefit systems is organisational improvement. While they are trying to improve efficiency and effectiveness, public sector organisations need to change some organisational issues such as information and communication systems, internal control system, risk control, to implement new procedures and rules etc.

The fifth advantage, learning and innovation, provide better service and quality of performance. Authorities and management accountability and transparency are influenced by the need for improvement and learning process. As emphasised by Hans de Bruijn (2002), products formulation and performance targets create transparency, which is an incentive for innovation in the organisation. Transparency, accountability, better organisation and leadership contribute to acceptance of new ideas, innovations and they are stimulative for 


\section{Neda Vitezić \\ Beneficial effects of public sector \\ performance measurement}

the achievement of better outputs and outcomes with the purpose of a better life.

In any case, performance measurement has positive effects and benefits. Researchers and practitioners no longer argue against performance measuring, but the question is "how to construct good measures" (Kelly and Rivenbark, 2003, p.122). In the beginning, it is important to have a clear mission and strategy and to accordingly select measures, which reflect strategic and operational goals, and to be aligned with service goals and objectives.

However, establishment of a measurement system also has some side effects which should not be considered as negative, but as additional effects for establishing the effective measurement. One of these effects is increase in costs for establishing and maintaining the performance system. It is important that the benefits of measurement are greater than costs. Another side effect might result from the measuring - a danger of too many measures and negative effect in the sense of inefficiency. Of course, the right measure in determining the necessary indicators which will explain realisation of target values must be found. However, a bigger problem lies in setting of goals, which should not only be measurable, but also achievable. Although some researchers emphasised negative effects, such as dysfunctional aspects of performance measurement in public sector (Pidd, 2005, p. 482), tables which can be a misleading way of presenting performance data, leading to apparent differences in performance when there is no evidence for this (Goldstein and Spiegelhalter, 1996), there are still more benefits that emerge from measuring performance, and there are more advantages than in cases in which there is no measuring system.

\section{Conclusion}

The paper addresses the need for conducting measurement of performance in the public sector in order to achieve better quality of services and, in general, better performing. It attempts to show benefits of performance measurement from the point of view of an emerging country. Performance is measured in order to improve the efficiency and effectiveness of managing and organising performance of the public sector. Orientation is primarily on quality measurement, which should be the final goal of public sector performance. Balanced measurement systems force the public sector to look and move forward instead to accept things the way they are. In Croatia as an emerging country, performance measurement becomes increasingly important 


\section{Neda Vitezić \\ Beneficial effects of public sector performance measurement}

because of a higher degree of democracy and involvement of citizens and it becomes utilised more and more among local governments and services. The focus of measurement is mostly on economy and efficiency, but very rarely, or not at all, on effectiveness. This is normal, due to easier availability of cost and efficiency measures.

There are beneficial effects of performance measurement which exceed possible negative effects. All beneficial effects related to behaviour changing, transparency, accountability, organisation and leadership improvements, willingness to learn and to innovate processes, could be abridged to a few key points: measurement of the public sector is even more important than measurement in private sector, because in public sector, there is an issue of expenditure of resources of all the tax payers and citizens. Correct and timely measurement achieves better work quality of public sector services and it finally fulfils the purpose of their existence, which is to improve the life quality of all the beneficiaries and to create a welfare society.

Dr. Neda Vitezić je redna profesorica na Ekonomski fakulteti Univerze v Reki za področja finančne analize in revizije poslovanja podjetij, analize poslovanja javnega sektorja ter kontrolinga. Na fakulteti je predstojnica podiplomskega specialističnega študija Kontrolinga. Je članica več znanstvenih in strokovnih združenj, med njimi Hrvaškega društva ekonomistov, Hrvaškega društva računovodij, Hrvaškega društvu finančnih analitikov. 


\section{Neda Vitezić \\ Beneficial effects of public sector \\ performance measurement}

\section{Bibliography}

- $\quad$ Adcroft, A.,Willis, R.(2005): International Journal of Operations \& Production Management, Vol.18 No.5 pp.386-400.

- $\quad$ Bititci,U.S., Martinez,V.,Albores,P.(2005): “Measuring and managing performance in extended enterprises", International Journal of Operations \& Production Management, Vol. 25.No.4 pp.335-353.

- Bolton, M.(2003): "Public sector performance measurement: delivering greater accountability", Work Study, Vol. 52.No.1.pp.20-24.

- Brujiin, H.de (2002):"Managing Performance in the Public Sector", Routledge, London and N.Y.

- Ghobadian, A.,Ashworth, J.(1994): "Performance Measurement in Local Government -Concept and Practice", International Journal of Operation \& Production Management, Vol.14 No.5, pp.35-51.

- Goldstein,H., Spiegelhalter, D.J. (1996): „League tables and their limitations: statistical issues in comparisons of institutional performance", Journal of the Royal Statistical Society, A, Vol.159, pp.385-443.

- Hansell B.(2002):"Five words of wisdom", Public management, Washington. Vol.84, pp. 33-36.

- Hood,C. (1991): "A public management for all seasons", Public Administration, Vol.69, Spring, pp. 3-19.

- Kaplan,R.,Norton,D.,(1992): “ The balanced scorecard-measures that drive performance", Harvard Business Review, Vol.70., No1, pp. 123-146

- Kelly,M. J., Rivenbark,C. W.( 2003): “Performance Budgeting for State and Local Government", M.E. Sharpe,Inc.

- Meyer, C.( 1994):"How the right measures help teams excel", Harvard Business Review, Vol.3, pp.99-122.

- Meyer,W., Marshall (2002):"Rethinking Performance Measurement" Beyond the Balanced Scorecard, Cambridge University Press, UK.

- Pidd,M. (2005):"Perversity in public service performance measurement", International Journal of Productivity and Performance Management, Vol.54., No. 56, pp. 482-493.

- Vitezić,N., Knez-Riedl J.(2005): "The use of financial and non-financial measures in decision-making process of enterprises performance in transition economy" Sixth International Conference on "Enterprise in Transition", University of Split, Faculty of Economics Split, May, 26-28,2005. CD ROM - Full papers, pp.247-259

- Zakon o proraćunu(2003), "Narodne novine" Republike Hrvatske, No.96. 


\section{POVZETEK}

\section{UGODNI UČINKI MERJENJA UČINKOVITOSTI V JAVNEM SEKTORJU}

Ta raziskava preučuje, koliko se $v$ hrvaški lokalni upravi trenutno uporabljajo sistemi za merjenje učinkovitosti, ovire pri uporabi nekaterih kvalitativnih meril ter prednosti sistema merjenja v učinkovitosti javnega sektorja. Danes je okolje izredno kompleksno in javni sektor se ni mogel izogniti splošnim usmeritvam, ki jih narekujeta globalizacija in demokratska rast, ki krepi raven javne udeležbe $\checkmark$ procesu odločanja. Poleg tega se spreminja vedenje ljudi in njihov odnos do javnih storitev, ljudje hočejo biti obveščeni o svojih pravicah. Z vse intenzivnejšo demokratično udeležbo se povečuje tudi pritisk državljanov in zakonodaje, ki zahtevata odgovornejšo porabo javnih prihodkov ter preglednost pri poročanju o doseženih rezultatih. To vpliva tudi na lokalne oblasti, ki tako začnejo bolj odgovorno porabljati denar, njihovi ukrepi pa so učinkovitejši. Poudarjajo se uspešnost, učinkovitost in ekonomija, ki so zelo pomembni za učinkovitost javnega sektorja. Produkcijo nadomeščajo rezultati. Njihovo merjenje zahteva kvalitativno oceno, ki pa je $v$ javnem sektorju otežena, saj se $v$ praksi pokaže veliko težav pri merjenju neoprijemljivih elementov.

„Učinkovitost" je večpomenska beseda, ki implicira delovanje, dinamiko in prizadevanje za izboljšave, s stališča lokalne oblasti ali storitev pa je tudi večdimenzionalna. Danes se javne storitve vse bolj usmerjajo $v$ dobiček in ukrepi za povečanje učinkovitosti sodijo med končne rezultate, ki se izražajo prek tekmovalnosti in finančnih dobičkov. Vodje lokalnih organov oblasti si prizadevajo povečati kakovost opravljanja storitev, eden njihovih glavnih ciljev pri tem pa je povečanje operativne učinkovitosti in uspešnosti ter učinkovito izvajanje programov.

Na podlagi odgovorov, podanih med pogovori z notranjimi revizorji treh lokalnih uprav, se navaja nekaj omejitev. Nanašajo se na:

Notranji postopek

- šibek sistem notranjega nadzora

- neusposobljenost zaposlenih

- odpornost proti spremembam

Tehnologija

- ni razvitega informacijskega in komunikacijskega sistema

- pomanjkanje ustrezne opreme

- pomanjkanje znanja 


\section{Neda Vitezić \\ Beneficial effects of public sector \\ performance measurement}

Upravljanje in vodstvo

- nejasna opredelitev vizije in strategije

- šibak sistem merjenja učinkovitosti

- vmešavanje politike

$\mathrm{Na}$ Hrvaškem poteka prenova javne uprave, katere cilji so povečanje učinkovitosti, davčna razbremenitev, povečanje pristojnosti in nepristranskosti zaposlenih $v$ javni upravi. Tako se nekaj sprejetih ukrepov, s katerimi bi zmanjšali te omejitve, nanaša na: uvedbo notranje finančne kontrole, uvedbo načrtovanja programov, izobraževanje notranjih revizorjev, posodobitev informacijskega sistema, depolitizacijo.

Raziskave so pokazale na nekaj značilnosti merjenja učinkovitosti javnega sektorja, in sicer na:

- obveznosti, tj. stroški, se merijo pogosto, rezultati pa redko,

- kvalitativni vidik storitev, tj. rezultat, se ne meri,

- storitve $v$ javnem interesu se merijo pogosteje od drugih vrst poslovnih dejavnosti,

- merjenja niso temeljita in stalna,

- merjenje ne odraža ciljne vrednosti,

- načrt ni povezan s ciljem in strategijo.

Večdimenzionalnost $v$ učinkovitosti javnega sektorja sili organizacije $v$ to, da so zavezane zaželenim izidom. Tako so ključna merila učinkovitosti produktivnost, učinkovitost, uspešnost in kakovost. Koncept "ekonomije", "učinkovitosti" in "uspešnosti" v javnem sektorju dobro poznajo že več kot deset let. Zanimivo pa je, da se $v$ praksi ta koncept še vedno ne sprejema popolnoma. Zlasti še vedno obstajajo težave v merjenju učinkovitosti, ki zahteva več kvalitativnih podatkov. $\vee$ novih državah je opredelitev tega koncepta še vedno nejasna in se razlaga različno, odvisno od organov oblasti. Razlogi za to tičijo $\checkmark$ naravnanosti in organizacijski ureditvi, $v$ raznolikosti nalog, tehničnih težavah, stopnji znanja in usposobljenosti.

Merjenje je bilo doslej usmerjeno navznoter in obravnavalo je predvsem učinkovitost, zlasti ekonomijo.

Usmeritev $v$ merila za povečanje kakovosti in učinkovitosti $v$ delovanju javnega sektorja zadržuje uporabnost BSC. Trenutno je najpomembneje poiskati prave ukrepe in jih uravnovesiti glede na poglavitna pričakovanja. Prirejena uravnotežena kartica rezultatov je še vedno zelo uporabno orodje, saj spodbuja k razmisleku o doseženih ciljih glede na zadano nalogo. 


\section{Neda Vitezić \\ Beneficial effects of public sector performance measurement}

Naloga je vsekakor opravljena, če je bila določena strategija in so bili izdelani ustrezni načrti. $V$ hrvaškem javnem sektorju pa pogosto ni tako, zato se model ne uporablja. Obstaja tudi težava z izbiro ustreznih ukrepov, ki morajo biti povezani in usklajeni, če hočejo podati odgovore na vprašanja, postavljena $\checkmark$ okviru vsakega pričakovanja. To je naslednja težava, saj je vse odvisno od postavljenega cilja, od strokovne usposobljenosti in znanja vodstva in zaposlenih ter od informacijsko-komunikacijskih povezav in razpoložljive tehnologije.

Z vidika učinkovitosti javnega sektorja $v$ novi državi je mogoče pozitivno plat sistema merjenja učinkovitosti strniti takole: prva prednost je povezana $s$ spremembo vedenja organov oblasti in razumevanjem potrebe po postavljanju izmerljivih ciljev.

Druga prednost je preglednost in odgovornost, tretja prednost lokalnih in državnih uradnikov ter vodij je vodenje, ki je veliko boljše, če obstaja sistem merjenja izvajanja nalog in delovnih rezultatov, zlasti postavljenih ciljev. Četrta prednost, ki jo prinašajo sistemi nagrajevanja učinkovitosti, je organizacijsko izboljšanje, peta pa učenje in inovacije, kar zagotavlja boljšo storitev in kakovost izvedbe.

Ima pa vzpostavitev sistema merjenja nekaj stranskih učinkov, na katere ne bi smeli gledati negativno, temveč bi jih morali obravnavati kot dodatne dejavnike, ki vplivajo na vzpostavitev učinkovitega merjenja. 